\title{
Development of the draft guidelines of the decommis- sioning plan for a nuclear power plant in Korea
}

\section{국내 원자로시설 해체계획서 세부 작성지침(안) 개발}

Jungmin Lee and Joohyun Moon*

Dongguk University-Gyeongju, 123 Dongdae-ro, Gyeongju, Gyeongbuk, Korea

이정민, 문주현*

동국대학교, 경상북도 경주시 동대로 123

(Received March 12, 2013 / Revised June 7, 2013 / Approved August 2, 2013)

It is essential to prepare the decommissioning plan for a nuclear power plant (NPP) for the safe decommissioning of the NPP, minimization of the generation of decommissioning wastes, and protection of human beings and environment. Although Kori unit 1 and Wolsong unit 1 will be destined to their decommissioning in Korea in the near future. there is no provisons about preparing the decommissioning plan. In this paper, therefore, the draft guidelines of the decommissioning plan for a NPP were developed by considering the domestic situation, based on the comparative analyses of the regulatory guidelines of the decommissioning plan in U.S., U.K. and France. The draft guidelines are expected to play an important role to modify the domestic laws and regulations on the decommissioning of the NPP, and to give a license holder in charge of decommissioning the detailed instructions for preparing it in advance.

Key words: Nuclear power plant, Decommissioning plan, Draft guidelines, Decommissioning wastes

원자로시설 해체계획서 작성은 원자로시설의 안전한 해체, 해체폐기물의 발생 최소화, 사람과 환경 보호 등을 위해 원자로 시설 해체에 앞서 반드시 필요하다. 우리나라는 고리 1호기, 월성 1 호기가 머지않은 시기에 해체를 맞이하게 되지만, 해체 계획서를 작성하는데 필요한 관련 세부 지침이 미비한 상황이다. 이에 따라 본 논문에서는 IAEA의 원자력 국제 안전기준 과 원자로시설 해체경험과 선진화된 규제체계를 보유하고 있는 미국, 영국, 프랑스의 해체계획서 작성 지침을 비교분석하 고 국내 상황을 감안하여 원자로시설 해체계획서 세부 작성지침(안)을 개발하였다. 본 논문에서 개발한 작성지침(안)은 국 내 원자로시설 해체 관련 법령을 정비하고 해체사업자가 원자로시설을 해체하고자 할 때 미리 준비사항을 알려주는 역할을 할 것으로 기대되고 있다.

중심단어 : 원자로시설, 해체계획서, 세부 작성지침(안), 해체폐기물

*Corresponding Author. E-mail: jhmoon86@dongguk.ac.kr, Tel: +82.54.770.2208 
Jungmin Lee. et al : Development of the draft guidelines of the decommissioning plan for a nuclear power plant in Korea

\section{1. 서 론}

원자로는 설계수명에 다다르면 안전성을 평가하여 계 속운전을 하거나 영구정지 되는데 이처럼 영구정지가 결 정된 원자로는 사용후핵연료 인출 및 이전, 냉각재 배수, 제염 등 원자로 해체를 위한 준비를 하게 된다. 여기서 원 자로 해체란 '효용가치를 상실한 원자력 시설을 주변 환경 으로부터 안전하게 영원히 퇴출하기 위해 취해지는 모든 기술적·관리적 활동'[1]으로 정의한다.

원자로 해체는 최소 몇 년 이상의 시간이 소요되는 장 기 업무로서, 그 기간 중에 다양한 해체 폐기물이 대량으 로 발생한다. 상대적으로 단기간에 대량으로 발생하는 해 체폐기물을 적절히 분류, 처리하지 못하면 상당한 처분부 담이 뒤따르며 또한 방사능을 띤 원전 계통과 기기를 해체 할 때 작업자의 방사선피폭은 물론 환경으로의 방사능 누 출이 발생할 수 있다. 이 때문에 현재 원자로를 운영하는 대다수 국가는 사업자에게 원자로를 해체하기 전에 치밀 한 해체계획을 수립할 것을 요구하고 있다. 심지어는 건설 전에 해체 폐기물의 발생량을 최소화할 수 있도록 해체를 고려하여 원자로를 설계할 것을 요구한다.

우리나라의 경우, 현재 고리 1 호기와 월성 1 호기가 안 전성 심사를 거쳐 계속운전을 하고 있거나 계속운전 여부 를 결정하기 위한 안전성 심사를 진행 중에 있다. 이들 원 자로 중 하나가 계속운전을 하지 못하게 될 경우, 인근 호 기와의 공용설비 가동기간 등에 따라 달라질 수 있으나 10 년 이내에 우리나라도 원자로를 해체하게 될 가능성 이 있다. 또한 2011년 3월 발생한 일본 후쿠시마 원전 사 고는 설계수명 전이라도 원자로를 조기에 해체할 가능성 이 있음을 보여주고 있다. 그리고 2011년 7월 국제원자력 기구는 우리나라를 대상으로 수행한 통합규제검토서비스 (Integrated Regulatory Review Service)를 통해 원자로 건 설 단계 시부터 해체 계획을 수립하고 운영기간 중 주기적 으로 갱신할 것을 권고하였다.

우리나라는 「원자력안전법」제 28 조(발전용원자로 및 관계시설의 해체)와 동법 시행규칙 제 26 조(원자로시설의 해체계획 승인신청)에서 원자로 해체와 관련하여 규정하 고 있다. 하지만 이들 규정은 원자로 해체 전 원자력안전 위원회에 해체계획서를 제출해야 한다는 사실과 이 해체 계획서에 포함되어야 하는 일반 항목만을 정하고 있을 뿐 이다. 원자로 영구정지에서 부지 복원에 이르는 시간대에 대한 구체적 인허가 절차와 해체계획서 작성에 대한 세부 지침은 부재한 상황이다. 이중 원자로 해체와 관련한 인허 가 절차는 한국원자력안전기술원을 중심으로 연구를 진 행 중에 있어 조만간 구체적 절차가 마련될 것으로 보인다.
따라서 본 논문에서는 원자로시설 해체계획서 작성에 관 한 세부지침에 초점을 맞추기로 하고 이를 위해, IAEA 원 자력 국제안전기준과 발전용원자로 해체 경험을 다수 보 유한 미국, 영국, 프랑스의 해체계획서 작성과 관련한 절 차와 규제지침을 조사·분석하고, 국내 상황을 반영하여 원자로시설 해체계획서 작성항목과 세부지침을 개발·제 시하기로 한다.

\section{2. 국내외 원자로시설 해체계획서 작성지침 현황}

\subsection{IAEA}

국제원자력기구는 원자력을 이용하는 모든 국가들 의 안전을 위해 규제기준의 척도를 제시하고 있으며 발 전용 원자력이용시설의 해체와 관련한 규제요건을 WSR-5, "Decommissioning of Facilities Using Radioactive Material(2006)"에 수립하고 이에 대한 상세한 지침을 WS-R-2.1, "Decommissioning of Nuclear Power Plants and Research Reactors"에서 제시한다. 두 규제요건에서 는 해체와 관련하여 국가와 운영자 및 규제기관의 책임 정 의와 해체절차를 비롯한 해체계획서 및 그 외 요건들을 수 록하고 있다.

IAEA는 해체전략을 수립하는 운영자가 반드시 당해 연도의 국가정책 및 폐기물관리를 준수하여 해체를 계획 하도록 정의하고 있다. 또한 즉시해체를 우선적인 선택사 항으로 지정하고 있으나 국가 상황에 따라 즉시해체를 시 행하지 못하는 경우에는 타당성과 안전성을 효율적으로 나타내는 문서들을 첨부하여 최종상태가 환경으로의 방사 성 물질의 유출과 대중 및 작업자에게 규제기준 이상의 피 폭을 야기하지 않음을 입증시키도록 권고한다. 준비되는 해체계획서는 3 단계, 즉, 설계, 운영, 운영정지 전 단계에 서 수립하고 특히 운영단계 동안 운영자는 적어도 5 년마 다 주기적으로 해체계획서를 갱신하여 상세한 최종해체계 획서를 완성해야 한다고 기술하고 있다[1][2].

IAEA의 Safety Reports Series No. 45, "Standard Format and Safety Related Decommissioning Documents" 에는 원자력을 이용하는 국가들이 대중 및 작업자와 환경 을 보호하고 위해를 범하지 않도록 하는 최소한의 해체 계획 수립을 위한 작성지침을 정의하고 있다. Table 1은 IAEA가 권고하는 해체계획서 항목 및 세부항목이다. 대부 분의 원자력 선진 국가들은 그들의 해체계획서 작성지침 을 수립할 때, 이 지침을 바탕으로 수립하고 있다. 
Jungmin Lee. et al : Development of the draft guidelines of the decommissioning plan for a nuclear power plant in Korea

Table 1 . The contents in decommissioning plan required by IAEA's safety standards[3]

\begin{tabular}{|c|c|c|c|}
\hline 1. & Introduction & 9.3 . & Hazard analysis of normal decommissi- \\
\hline 2. & Facility Description & 9.4 & $\begin{array}{l}\text { oning activities } \\
\text { Hazard analysis of normal events and }\end{array}$ \\
\hline 2.1 . & Site location and description & & incidents \\
\hline 2.2 . & Building and system description & 9.5 & Assessment of potential consequences \\
\hline 2.3 . & Radiological status & 9.6. & Prevent and mitigating measures \\
\hline 2.3.1. & Contaminated structures & 9.7. & Risk assessment \\
\hline 2.3.2. & $\begin{array}{l}\text { Contaminated systems and } \\
\text { equipment }\end{array}$ & 9.8 . & $\begin{array}{l}\text { Comparison of analysis results with rele- } \\
\text { vant safety criteria }\end{array}$ \\
\hline 2.3.3. & Surface soil contamination & 9.9. & Conclusion \\
\hline $\begin{array}{l}2.3 .4 \\
2.3 .5\end{array}$ & $\begin{array}{l}\text { Subsurface soil contamination } \\
\text { Surface water contamination }\end{array}$ & 10. & Environmental Assessment \\
\hline 2.3 .6 & Groundwater contamination & 10.1. & Background data \\
\hline 2.4 . & Facility operation history & $\begin{array}{l}10.2 \\
10.3\end{array}$ & $\begin{array}{l}\text { Description of project } \\
\text { Environmental protection programme }\end{array}$ \\
\hline $\begin{array}{l}2.4 .1 \\
2.4 .2\end{array}$ & $\begin{array}{l}\text { Authorized activities } \\
\text { Licence or authorization history }\end{array}$ & $\begin{array}{l}10.4 . \\
10.5\end{array}$ & $\begin{array}{l}\text { Effluent monitoring programme } \\
\text { Effluent control programme }\end{array}$ \\
\hline 2.4.3. & $\begin{array}{l}\text { Spills and occurrences affecting } \\
\text { decommissioning }\end{array}$ & 11. & Health and Safety \\
\hline $\begin{array}{l}2.4 .4 . \\
2.4 .5\end{array}$ & $\begin{array}{l}\text { Previous decommissioning activities } \\
\text { Prior on-site burial }\end{array}$ & $\begin{array}{l}11.1 . \\
11.2 .\end{array}$ & $\begin{array}{l}\text { Radiation protection plan } \\
\text { Nuclear criticality safety }\end{array}$ \\
\hline 3. & Decommissioning Strategy & $\begin{array}{l}11.3 . \\
11.4 .\end{array}$ & $\begin{array}{l}\text { Industrial health and safety plan } \\
\text { Audits and inspections }\end{array}$ \\
\hline $\begin{array}{l}3.1 . \\
3.2 .\end{array}$ & $\begin{array}{l}\text { Alternatives considered } \\
\text { Rationale for chosen strategy }\end{array}$ & $\begin{array}{l}11.5 . \\
11.6 .\end{array}$ & $\begin{array}{l}\text { Record keeping programme } \\
\text { Optimization analyses and programme }\end{array}$ \\
\hline 4. & Project Management & 11.7. & Dose estimation and optimization for \\
\hline $\begin{array}{l}4.1 . \\
4.2 .\end{array}$ & $\begin{array}{l}\text { Legal and regulatory requirements } \\
\text { Project management approach }\end{array}$ & $\begin{array}{l}11.8 . \\
11.9 .\end{array}$ & $\begin{array}{l}\text { major tasks } \\
\text { Clearance criteria } \\
\text { Final release criteria }\end{array}$ \\
\hline & $\begin{array}{l}\text { Project management organization and } \\
\text { responsibilities }\end{array}$ & 12. & Quality Assurance \\
\hline 4.4 . & $\begin{array}{l}\text { Task management organization and } \\
\text { responsibilities }\end{array}$ & $\begin{array}{l}12.1 . \\
12.2 .\end{array}$ & $\begin{array}{l}\text { Organization } \\
\text { Quality assurance programme }\end{array}$ \\
\hline 4.5 . & Safety culture & 12.3 . & Document control \\
\hline 4.6. & Training & 12.4. & Control of measuring and test equipment \\
\hline 4.7. & Contractor support & 12.5 . & Corrective actions \\
\hline 4.8 . & Schedules & 12.6 & Quality assurance records \\
\hline 5. & Decommissioning Activities & 12.7. & Audits and surveillance \\
\hline 5.1. & Contaminated structures & 12.8. & Lessons learned programme \\
\hline 5.2 . & Contaminated systems and equipment & 13. & Emergency Planning \\
\hline 5.3 . & Soil & 13.1. & Organization and responsibilities \\
\hline 5.4 . & Surface and groundwater & 13.2 . & Emergency situations \\
\hline 5.5 . & Decommissioning schedules & 13.3. & Records \\
\hline 6. & Surveillance and Maintenance & 14. & Physical Security and Safeguards \\
\hline $\begin{array}{l}6.1 . \\
6.2 .\end{array}$ & $\begin{array}{l}\text { Equipment and systems } \\
\text { Requiring surveillance and maintenance }\end{array}$ & $\begin{array}{l}14.1 . \\
14.2 .\end{array}$ & $\begin{array}{l}\text { Organization and responsibilities } \\
\text { Physical security programme and }\end{array}$ \\
\hline 7. & $\begin{array}{l}\text { Schedule for surveillance and } \\
\text { maintenance }\end{array}$ & 14.3 . & $\begin{array}{l}\text { measures } \\
\text { Safeguards programme and measures }\end{array}$ \\
\hline $\begin{array}{l}7.1 . \\
7.2 . \\
7.3 . \\
7.4 .\end{array}$ & $\begin{array}{l}\text { Waste Management } \\
\text { Identification of waste streams } \\
\text { Solid radioactive waste } \\
\text { Liquid radioactive waste }\end{array}$ & 15. & Final Radiation Survey \\
\hline 8. & $\begin{array}{l}\text { Waste containing both radionuclides and } \\
\text { other hazardous material }\end{array}$ & & \\
\hline $\begin{array}{l}8.1 . \\
8.2 .\end{array}$ & $\begin{array}{l}\text { Cost Estimate and Funding Mechanisms } \\
\text { Cost estimate and Funding mechanisms }\end{array}$ & & \\
\hline 9. & Safety Assessment & & \\
\hline $\begin{array}{l}9.1 . \\
9.2 .\end{array}$ & $\begin{array}{l}\text { Identification of relevant safety criteria } \\
\text { Operational limits and conditions }\end{array}$ & & \\
\hline
\end{tabular}


Jungmin Lee. et al : Development of the draft guidelines of the decommissioning plan for a nuclear power plant in Korea

\section{2 미국}

원자력시설의 최대 보유국으로 해체경험이 많은 미국 은 해체와 관련하여 “불필요한 시간적 지연 없이 위험을 감 소시키고 환경과 대중 및 작업자의 건강 보호를 보장”하는 정부정책에 따라 여전히 지속적인 원자력 발전을 위해 해 체가 진행 중에 있다.

미국은 개인사업자가 운영하는 상업용원자로의 해체 의 경우 미국원자력규제위원회(Nuclear Regulatory Commission, 이하 NRC)에서 모든 해체사업을 전적으로 규제 하고 있으며 미국 연방법 10CFR50.82(a)(4)(i)에 따라, 원 자로 운영 허가소지자는 원자로 영구정지 후 2년 이내에 $\mathrm{NRC}$ 에 정지 후 해체 활동보고서(Post-shutdown Decommissioning Activity Report, 이하 PSDAR)를 제출하도록 해야 한다[4]. 이 PSDAR의 목적은 1) 허가소지자가 계획 한 해체 활동에 대한 정보를 일반인에게 제공, 2) 해체 활 동에 대한 $\mathrm{NRC}$ 의 감독 지원, 3) 허가소지자가 계획한 해체 활동에 대한 비용 및 기금의 보증, 3 ) 기존 환경영향평가서
와 계획한 해체 활동의 환경영향을 비교, 확인 등이다[5].

PSDAR에 포함될 항목과 기재내용은 Reg. Guide 1.185 에 의해 규정되어 있다. 이 지침에 따르면, PSDAR 는 계획한 해체 활동, 주요 해체 활동의 일정, 예상 비용 및 부지특성을 반영한 환경영향 평가 결과를 포함해야 한다. 이 중 부지특성을 반영한 환경영향 평가는 NUREG-0586, "Final Generic Environmental Impact Statement on Decommissioning of Nuclear Facilities"와 NUREG-1496, "Generic Environmental Impact Statement in Support of Rulemaking on Radiological Criteria for License Termination of NRC-Licensed Nuclear Facilities"에서 정한 기존 의 환경영향평가와 비교하여야 한다. 만약 기존의 환경영 향평가에서 계획된 해체 활동을 다루고 있다면, 허가소지 자는 이를 PSDAR에 표시해야 한다. 기존의 환경영향평가 서에서 다루어지지 않았었다면, 허가소지자는 반드시 해 체 활동과 관련된 환경영향을 평가하여 제출해야 한다[5]. Table 2에 Reg. Guide 1.185에서 요구하는 PSDAR의 작성 항목과 기재내용을 정리하였다.

Table 2. The contents in PSDAR required by U.S. Reg. Guide 1.185[4]

\begin{tabular}{|c|c|}
\hline Items & Contents \\
\hline \multirow[t]{4}{*}{$\begin{array}{l}\text { - Planed decommissioning work's } \\
\text { introduction }\end{array}$} & $\begin{array}{l}\text { - Decommissioning objective: to inform regulatory authority and public to all } \\
\text { decommissioning and special work. }\end{array}$ \\
\hline & - Description of selected decommissioning method. \\
\hline & $\begin{array}{l}\text { Description of major work's list and explain. } \\
\text { - description of programme. } \\
\text { - description in detailed with work's characteristic. } \\
\text { - decommissioning work required regulation and supervision as special work should be } \\
\text { described in detailed than general work. } \\
\text { - decommissioning work from spent fuel's permanent withdrawal to license completion. }\end{array}$ \\
\hline & $\begin{array}{l}\text { PSDAR doesn't contain radiation protection plan, security, quality assurance, but these } \\
\text { information may be required when FSAR is updated periodically. }\end{array}$ \\
\hline \multirow[t]{3}{*}{$\begin{array}{l}\text { Planed decommissioning work's } \\
\text { schedule }\end{array}$} & $\begin{array}{l}\text { Objective providing schedule: as notifying regulatory authority, they can establish plan of } \\
\text { commitment of regulation sources. }\end{array}$ \\
\hline & - Description of correlation between major decommissioning work. \\
\hline & $\begin{array}{l}\text { Description of expected date which is worried to increase in potential hazard for public, } \\
\text { worker and environmental. } \\
\text { - description of following work's wanted launch and completion date; acceptance of } \\
\text { license complement plan, license activities to ensure requirement related transport of major } \\
\text { components, ISFSI's acceptance and license, spent fuel's withdrawal, etc. } \\
\text { - notification to state government when schedule is changed } \\
\text { - major schedule of immediate future write in year/month. }\end{array}$ \\
\hline $\begin{array}{l}\text { Decommissioning expensive } \\
\text { assessment }\end{array}$ & - The newest assessment for expected decommissioning expenses \\
\hline - Environmental impact & $\begin{array}{l}\text { Description of validity for conclusion that environmental impact (during decommissioning) } \\
\text { is included in previously published environmental impact assessment. }\end{array}$ \\
\hline
\end{tabular}


Jungmin Lee. et al : Development of the draft guidelines of the decommissioning plan for a nuclear power plant in Korea

\section{3 영국}

영국정부는 1990년 이후 신규 원전건설이 없었던 이래 로 최근 신규원전을 건설하는 계획을 세웠다. 따라서 영국 의 모든 원전해체 관련 업무를 총괄적으로 수행하는 정부 기관인 원자력 해체국(Nuclear Decommissioning Agency, 이후 NDA)은 2023 년까지 노후화된 18 개 원전을 해체
하기로 결정하고 "해체활동은 고려되는 요인들이 가능한 합리적이고 실용적으로 유지하도록 수행되어야 한다”는 정부정책에 따라 해체활동에 착수하고 있다[6][7].

따라서 영국은 원자로의 영구정지일 전에 원자로의 운 영시점부터 매 5 년마다 운영자가 갱신한 방사성폐기물의 관리 및 처분 계획을 포함한 해체전략계획(Licensee's decommissioning strategies)을 규제기관(Health \& Safety Executive, 이하 HSE)에 제출하고 환경부처의 자문을 받

Table 3. The contents in the strategy plan for decommissioning by U.K's requirement[9]

\begin{tabular}{|c|c|}
\hline Items & Contents \\
\hline $\begin{array}{l}\text { Description of the } \\
\text { Strategy }\end{array}$ & $\begin{array}{l}\text { Decommissioning objectives and policy, strategy for decommissioning each nuclear facility (timescale, } \\
\text { project milestones and targets, method of implementation, proposed disposal routes the radioactive and non- } \\
\text { radioactive wastes). }\end{array}$ \\
\hline $\begin{array}{l}\text { Consistency with } \\
\text { government policy }\end{array}$ & $\begin{array}{l}\text { - Demonstrate that their proposed strategy is consistent with government policy and identjfy and justify any } \\
\text { differences. }\end{array}$ \\
\hline $\begin{array}{l}\text { Selection of preferred } \\
\text { option }\end{array}$ & $\begin{array}{l}\text { A description of the options, major assumptions (reasonably foreseeable closure scenarios, the availability of } \\
\text { disposal routes for radioactive wastes, development of technology, the financial implications of proceeding on } \\
\text { different time-scales), significant uncertainties with the approach for their resolution, selection process and } \\
\text { justification of the preferred option, maintenance of the decision process. }\end{array}$ \\
\hline $\begin{array}{l}\text { Time-scales for } \\
\text { decommissioning }\end{array}$ & $\begin{array}{l}\text { Definition and justification of the time-scales (programme for the main and buildings, and the dares when } \\
\text { buildings and land will be available for reuse: major decision dates for selecting options) }\end{array}$ \\
\hline $\begin{array}{l}\text { Progressive and } \\
\text { systematic reduction of } \\
\text { the hazard }\end{array}$ & $\begin{array}{l}\text { Observance of the requirement to reduce the hazards in a progressive and systematic manner, justification of } \\
\text { the order and time-scales on which they will address each hazard. }\end{array}$ \\
\hline$\cdot$ Methods & $\begin{array}{l}\text { - Methods to be used for each stage of decommissioning (dismantling, decontamination, waste processing and } \\
\text { storage), demonstrate that these methods are technically practicable. }\end{array}$ \\
\hline - Structured approach & $\begin{array}{l}\text { Structured approach to decommissioning, integration and coordination of decommissioning strategies for } \\
\text { individual nuclear facilities on the same site. }\end{array}$ \\
\hline $\begin{array}{l}\text { Radioactivity waste } \\
\text { management and } \\
\text { disposal }\end{array}$ & $\begin{array}{l}\text { Decommissioning strategy coordinated with the strategy for radioactive waste management, quantities of } \\
\text { radioactive wastes (estimates of the volume, character and activity of radioactive waste), minimization of the } \\
\text { quantities producted and discharged, plan for the long term storage of radioactive wastes. }\end{array}$ \\
\hline $\begin{array}{l}\text { - Monitoring and } \\
\text { surveillance }\end{array}$ & $\begin{array}{l}\text { - Adequate arrangements for the continued surveillance, maintenance and monitoring of the facilities and the site } \\
\text { to the deferral of decommissioning for extended periods of time or the long term storage of radioactive wastes. }\end{array}$ \\
\hline $\begin{array}{l}\text { Corporate management } \\
\text { system, supporting } \\
\text { infrastructure and } \\
\text { retention of records }\end{array}$ & $\begin{array}{l}\text { - Extent of the corporate management system and supporting infrastructure to support the decommissioning } \\
\text { strategy over the full term of the project, retainment of the appropriate resources of suitably qualified and } \\
\text { experienced staff and existing knowledge base relating to the nuclear facilities required to support the } \\
\text { decommissioning project. }\end{array}$ \\
\hline - Environmental impact & - Environmental impact (guidance : EIADR99) \\
\hline $\begin{array}{l}\text { Demonstration of } \\
\text { financial provision }\end{array}$ & $\begin{array}{l}\text { Comprehensive estimates of the costs of decommissioning (major cost components with the distribution of } \\
\text { costs with time), any assumptions made on discount rates and the time-scales, details of the arrangements for } \\
\text { the funding of their nuclear liabilities, demonstration of the adequacy of the financial provision. }\end{array}$ \\
\hline - Public expectation & - Societal concern and public expectations with respect to decommissioning. \\
\hline
\end{tabular}


Jungmin Lee. et al : Development of the draft guidelines of the decommissioning plan for a nuclear power plant in Korea

아 이 계획을 심사를 통해 최적의 해체계획을 마련하도록 하고 있다. 이후 원자로를 영구정지하기로 결정하면 허가 소지자는 허가조건(License Condition 35)에 따라 전 해체 단계에 걸쳐 해체 안전성을 정당화하는 문서를 포함한 최 종 해체계획서를 수립하여 HSE에 제출한다[8].

영국의 원자로 해체계획서 작성에 관한 지침은 검사원 지침에서 찾을 수 있다. 이 지침에서는, 해체계획서는 해 체전략, 정부 정책과의 일관성, 선호하는 옵션, 해체 기간, 점진적이고 체계적인 위험 감소, 해체방법, 구조적 접근법, 방사성 폐기물의 관리 및 처분, 감시 및 관찰, 조직 관리 체 계, 지원 기반시설 및 기록 유지, 환경영향, 재정적 수단 입 증, 일반 대중의 기대 등을 작성 항목으로 포함하고 있다. 영국은 미국과 마찬가지로 부지 안전성 및 작업자의 안전 성, 해체활동으로 인한 위험도 및 품질보증은 별도의 안전 문서에서 기술한다[9]. Table 3 는 영국의 해체계획서 작성 지침을 정리한 것이다.

\section{4 프랑스}

프랑스는 원자로시설 해체 시 국제 원자력 기구(International Atomic Energy Agency, 이하 IAEA)의 권고 를 따라 원자로를 해체하고 프랑스의 원자로시설은 해체 가 완료될 때 까지 Decree no. 90-78(1990)를 준수해야 한 다. 프랑스 운영자는 영구정지일 최소 1 년 전에 decree $\mathrm{n}^{\circ} 1557$ 에서 요구하는 1) 선택한 상황을 정당화하고 다양 한 후속 해체단계를 나타내는 문서, 2) 영구정지 절차를 포 괄하고 그 이후 발전소 안전설비를 나타내는 안전성 분석 보고서, 3) 충분한 안전성 수준이 유지됨을 보증하기 위 한 일반 감시 및 정비 규정, 4) 해당 시설에 대한 소내 비상 계획 개정본을 포함하여 제출해야 한다[10]. 이들 문서에 포함되어야 할 항목과 기재사항은 Table 4 에 요약하였다.

\section{5 우리나라}

우리나라는 Table 5에서 보는 것처럼「원자력안전법」 제 28 조(발전용원자로 및 관계시설의 해체)와 동법 시행규 칙 제26조(원자로시설의 해체계획 승인신청)에서 원자로 시설 해체계획서에 관한 사항을 규정하고 있다. 「원자력 안전법」제 28 조제 1 항에서는 허가소지자가 원자로시설을 해체하려 할 때 해체계획서를 작성하여 미리 승인을 받아 야 한다는 것을 규정하고 있으며, 제 28 조제 2 항에서는 이
해체계획서에 포함되어야 할 7 가지 항목, 즉, 1) 발전용원 자로 및 관계시설의 해체방법 및 공사일정, 2) 방사성물 질 및 그에 따른 오염의 제거방법, 3) 방사성폐기물의 처 리 - 처분 방법, 4) 방사선으로부터의 재해를 방지하는 데 에 필요한 조치, 5) 방사성물질 등이 환경에 미치는 영향의 평가 및 그 대책, 6) 발전용원자로 및 관계시설의 해체에 관한 품질보증계획, 7) 그 밖에 위원회가 정하는 사항을 정 하고 있다. 그러나 우리나라는 앞서 살펴본 미국, 영국, 프 랑스와 같이 이들 항목에 대한 기재사항 등 세부 작성지침 을 규정하지는 않고 있다.

우리나라는 지금 고리 1호기, 월성 1호기에 대한 해체 를 준비해야 하는 상황에서 국내 폐기물 처분장이 단 한 곳만 있다는 점, 그 한 곳이 중·저준위만 수용한다는 점에 서 훗날 폐기물 관리측면에서 문제가 발생할 것으로 예상 된다. 특히 해체단계에서 발생되는 폐기물들은 운영단계 와 달리 증기발생기와 같은 부피가 큰 폐기물이 발생되기 때문에 처분장의 수용력이 포화가 될 것으로 예상된다. 그 러므로 현 운영자들이 해체계획을 통해 폐기물과 그 위해 를 최소화하고 방사능 누출을 막기 위한 폐기물 관리방안 수립할 수 있도록 국내 해체계획서 세부작성지침 개발이 시급한 상황이다.

\section{3. 국내 원자로시설 해체계획서 작성지침 개발}

\section{1 국내외 원자로시설 해체계획서 작성 항목 비교}

발전용원자로 및 관계시설(이하 ‘원자로시설’이라 함) 해체계획 수립의 목적은 해체단계에서 발생되는 방사성폐 기물들을 최소화하고 안전하게 처리·처분하기 위함도 있 지만 규제기관과의 소통을 위한 도구 및 규제기관의 규제 활동을 수립과 해당시설 주민들에게 안전하고 조속한 해 체활동을 알리기 위한 목적도 가지고 있다.

미국, 영국, 프랑스는 다수의 원자로 시설 보유국가로, 풍부한 해체경험을 바탕으로 개발한 상세한 해체계획을 수립하고 있다. 이들 국가들은 원자로시설 건설 단계부터 해체계획을 고려하고 원자로시설 해체를 앞두고는 제출 시점을 정하여 해체계획서 제출을 요구하고 있다. 미국의 경우 원자로 영구정지 전이나 영구정지일로부터 2년 이내 에 해체계획서를 규제기관에 제출해야 하며, 영국은 원자 
Jungmin Lee. et al : Development of the draft guidelines of the decommissioning plan for a nuclear power plant in Korea

Table 4. The contents in the application documents for decommissioning NPPs in accordance with France's requirements[8]

\begin{tabular}{|c|c|}
\hline Items & Contents \\
\hline $\begin{array}{l}\text { Document justifying } \\
\text { the chosen state and } \\
\text { indicating the stages } \\
\text { of the subsequent } \\
\text { decommissioning }\end{array}$ & $\begin{array}{l}\text { I. Descriptive aspect } \\
\text { A - original installation (design operating rules, maintenance history, incidents, modifications, description of the } \\
\text { initial physical and radiological state of the installation, that is to say the planned state at the end of the process of } \\
\text { final cessation of activities) } \\
\text { B - Decommissioning stages } \\
\text { 1. definition of the decommissioning stages } \\
\text { 2. description of the work that it is planned to carry out } \\
\text { 3. identification of the safety and radio-protection objectives } \\
\text { 4. taking into account the waste, discharges and conventional risks } \\
\text { 5. description of the decontamination methods adopted } \\
\text { 6. Declassification mode envisaged } \\
\text { 7. timetable envisaged } \\
\text { C - final state chosen (description of the final physical and radiological state intended after accomplishment of } \\
\text { the decommissioning phase) }\end{array}$ \\
\hline & $\begin{array}{l}\text { I. Justificatory aspect } \\
\text { A - Strategy adopted } \\
\text { 1. General doctrine } \\
\text { 2. Justification of the technical choices (including those for the radio-protection, waste, discharges and } \\
\quad \text { conventional risk aspects) and the timetable envisaged } \\
\text { B - Assessment of the impact of the installation and the site after attainment of the intended final state }\end{array}$ \\
\hline - Safety report & $\begin{array}{l}\text { Descriptive and demonstrative document for the safety provisions adopted in the installation during the } \\
\text { decommissioning phase } \\
\text { - Safety analyses of the installations for the processing, putting into storage or if necessary storage in situ of the } \\
\text { waste and effluent generated by the decommissioning }\end{array}$ \\
\hline $\begin{array}{l}\text { - General supervisory } \\
\text { and maintenance Uules }\end{array}$ & $\begin{array}{l}\text { - All of the general rules connected with the operation, supervision and maintenance of the installation during the } \\
\text { decommissioning phase } \\
\text { - Level of detail to be consistent with that of the safety report }\end{array}$ \\
\hline $\begin{array}{l}\text { - Updating of the } \\
\text { PUI(Plan d'Urgence } \\
\text { Interne) }\end{array}$ & - Internal emergency plan \\
\hline - Waste study & $\begin{array}{l}\text { - Management of waste produced by the decommissioning phase and procedures adopted } \\
\text { - An assessment, after optimization, of the amounts of waste and effluent generated by the decommissioning work } \\
\text { and the physico-chemical and radiologocal characteristics thereof; } \\
\text { - The types of waste deriving therefrom and the associated management procedures; } \\
\text { - The needs in terms of specific processing or pre-processing, temporary or permanent storage installations of the } \\
\text { waste generated by the decommissioning work to be taken into account, on-site or off site } \\
\text { - Description of the storage facility on site } \\
\text { - Containers for packing away the waste produced as well as those for carrying it away }\end{array}$ \\
\hline
\end{tabular}


Jungmin Lee. et al : Development of the draft guidelines of the decommissioning plan for a nuclear power plant in Korea

Table 5. The decommissioning-related provisions on the Nuclear Safety Act in Korea

NUCLEAR SAFETY ACT

ENFORCEMENT DECREE OF

THE NUCLEAR SAFETY ACT

Article 28. (1)A licensee who has determined to decommission his/her power nuclear reactor and its relevant facilities is required to submit their decommissioning plan to and obtain approval from the Nuclear Safety and Security Commission (NSSC) ahead of their decommissioning. The major modification of the decommissioning plan is required to obtain NSSC's approval. However, minor modifications determined by NSSC regulations could be made only by reporting to NSSC.

(2) In compliance with article (1), the decommissioning plan shall include the following.

1. Decommissioning methods and schedule of a power reactor and its relevant facilities;

2. Methods to remove radioactive material and contamination by it;

3. Waste treatment and disposal methods;

4. Measures needed to prevent radiation-induced disasters;

5. Assessment of and countermeasures against environmental impact due to radioactive materials;

6. Quality assurance plan for decommissioning of the power reactor and its relevant facilities; and

7. Others determined by NSSC regulations.

(3) NSSC shall confirm and inspect the state of progress for decommissioning of the power reactor and its relevant facilities before the completion of decommissioning.

(4) If NSSC recognizes that the licensee does not follow the decommissioning plan through confirmation or inspection in compliance with article (3), NSSC might order the licensee to correct or supplement it
Article 26. (1) A licensee who wants to obtain approval of the decommissioning plan for their nuclear facilities from NSSC shall submit to NSSC the application for approval of nuclear facilities decommissioning plan in due form as stated annex 13, along with the detailed decommissioning plan NSSC.

(2) If a licensee who has approval for nuclear facilities decommissioning from NSSC want to modify the nuclear facilities decommissioning plan in compliance with article 28-1 of the nuclear safety act, the licensee shall submit to NSSC the application for approval of the nuclear facilities decommissioning plan modification in due form as stated annex 14 , along with the related documents
로시설 운영 시점부터 5년마다 해체계획서를 규제기관에 제출하고 있다. 그리고 프랑스의 경우에도 영구정지일로 부터 1 년 이전에 해체계획서를 규제기관에 제출해야 한 다. 따라서 규제기관은 해체계획서를 접수한 후 해체계획 의 타당성을 심사하는 한편 주요 해체 일정 등을 고려하여 인허가 일정과 규제인력 투입계획 등을 수립하고 있다. 그 러나 우리나라는 원자로시설 해체계획서 제출 및 승인이 라는 간단한 절차만 기술되어 있고, 제출기한이 정해져 있 지 않아 사업자는 물론 규제기관도 원자로시설 해체에 대 해 효율적으로 대비하기 어려운 상황이다.

원자로시설의 해체 안전성을 확인하기 위해서는 원자 로시설 영구정지부터 해체완료에 이르는 전 기간 동안 이 루어지는 해체활동과 그로 인한 영향, 해체폐기물의 안전 한 관리 및 처분 등에 대한 내용을 체계적으로 기술해야 한
다. 이 때문에 미국, 영국, 프랑스는 원자로시설 해체계획 서 작성지침을 규제요건으로 규정하고 있다. 우리나라의 경우, 「원자력안전법」 제 28 조제 2 항에서 해체계획서에 포 함해야 할 항목을 제시하고 있지만, 이들 항목에 무엇을 어떻게 작성하는지를 정한 세부 작성지침은 없는 실정이 다. 이 때문에 해체사업자가 해체계획서를 작성하는데 애 로를 겪을 가능성이 높으며, 규제기관 측면에서도 원자로 시설 해체의 안전성 및 환경영향을 확인하는데 한계를 느 낄 수가 있다.

이에 국내 원자로시설 해체계획서 세부 작성지침을 개 발하기 위한 일환으로 미국, 영국, 프랑스와 우리나라의 해 체계획서 항목을 비교하였다. 이를 통해 우리나라 「원자 력안전법」에서 고려하지 못하고 있는 항목 등을 도출하 고자 하였다. 먼저 각 국가와 IAEA의 해체요건을 분석하 
Jungmin Lee. et al : Development of the draft guidelines of the decommissioning plan for a nuclear power plant in Korea

Table 6. Comparison of the contents in the application documents for decommissioning

\begin{tabular}{|c|c|c|c|c|c|}
\hline Contents & IAEA & U.S. & UK & France & Korea \\
\hline 1. Overview of Nuclear Facility & 0 & & & 0 & \\
\hline \multicolumn{6}{|l|}{ 2.Overview of decommissioning project } \\
\hline 1) Decommissioningpurpose & $\bigcirc$ & O & 0 & 0 & \\
\hline 2) Decommissioning schedule & $\bigcirc$ & ○ & $\bigcirc$ & O & $\bigcirc$ \\
\hline \multicolumn{6}{|l|}{ 3. Decommissioning strategy } \\
\hline 1) Options considered & $\bigcirc$ & & 0 & 0 & \\
\hline 2) Options selected & $\bigcirc$ & & $\bigcirc$ & ○ & \\
\hline 4. Decontamination and decommissioning method & $\bigcirc$ & $\bigcirc$ & $\bigcirc$ & $\bigcirc$ & $\bigcirc$ \\
\hline \multicolumn{6}{|l|}{ 5. Waste management and disposal } \\
\hline 1) Spent fuel management & $\bigcirc$ & $\bigcirc$ & $\bigcirc$ & $\bigcirc$ & \\
\hline 2) Radioactive waste management & $\bigcirc$ & $\bigcirc$ & 0 & 0 & $\bigcirc$ \\
\hline 3) Non-radioactive waste management & $\bigcirc$ & O & 0 & 0 & \\
\hline 6. Monitoring and maintenance & $\bigcirc$ & & & $\bigcirc$ & \\
\hline 7. Organization management & 0 & $\bigcirc$ & $\bigcirc$ & & \\
\hline \multicolumn{6}{|l|}{ 8. Safety management } \\
\hline 1) Safety assessment & $\bigcirc$ & 0 & O & 0 & \\
\hline 2) Risk assessment & 0 & & 0 & 0 & \\
\hline 3) Emergency plans & $\bigcirc$ & & & $\bigcirc$ & \\
\hline 4) Radiation protection plan & 0 & & & 0 & O \\
\hline 9. Cost estimation & $\bigcirc$ & O & 0 & & \\
\hline 10. Environmental impact & $\bigcirc$ & ○ & ○ & 0 & 0 \\
\hline 11. Public involvement & $\bigcirc$ & $\bigcirc$ & $\bigcirc$ & O & \\
\hline 12. Quality assurance & $\bigcirc$ & & & & 0 \\
\hline
\end{tabular}

여 대항목을 선별하고 선별된 각 대항목을 통합시켰다. 통 합시킨 대항목들을 다시 각 국가와 IAEA 요건, 우리나라의 대항목가 비교하고 각 해체지침에서 포함되는 항목들을 표시하여 통계를 내었다. 이들 지침의 비교결과는 Table 6 에 요약하였다. 비교결과, IAEA 요건의 경우 모든 항목을 포함하고 있었으나 미국, 영국, 프랑스의 경우 각각 시설 개요 및 방사선방호 및 비상계획과 조지관리 등 몇몇의 포 함되지 않은 항목이 있었다. 그러나 포함되지 않은 항목과 관련하여 대부분의 국가들은 해체계획서와 별도로 문서화 하여 첨부하도록 규정하고 있다. 그러나 우리나라의 경우,
오직 6개의 항목만이 존재하고 있어 국내 해체계획서 작성 지침 개발이 필요한 상황이다.

\section{2 국내 원자로시설 해체계획서 작성지침 개발}

본 연구를 통해 국내「원자력안전법」과 미국, 영국, 프랑스의 지침을 분석하고 국내 원자로시설 해체계획서 기재사항을 도출하기 위해 첫째, 기존 법체계와 일관성을 유지하도록 해체계획서에 포함해야 하는 대항목을 「원자 력안전법」 제 28 조제 2 항에서 규정한 항목을 따르는 것으 
Jungmin Lee. et al : Development of the draft guidelines of the decommissioning plan for a nuclear power plant in Korea

Table 7. The contents in the draft guidelines of the decommissioning plan for NPPs

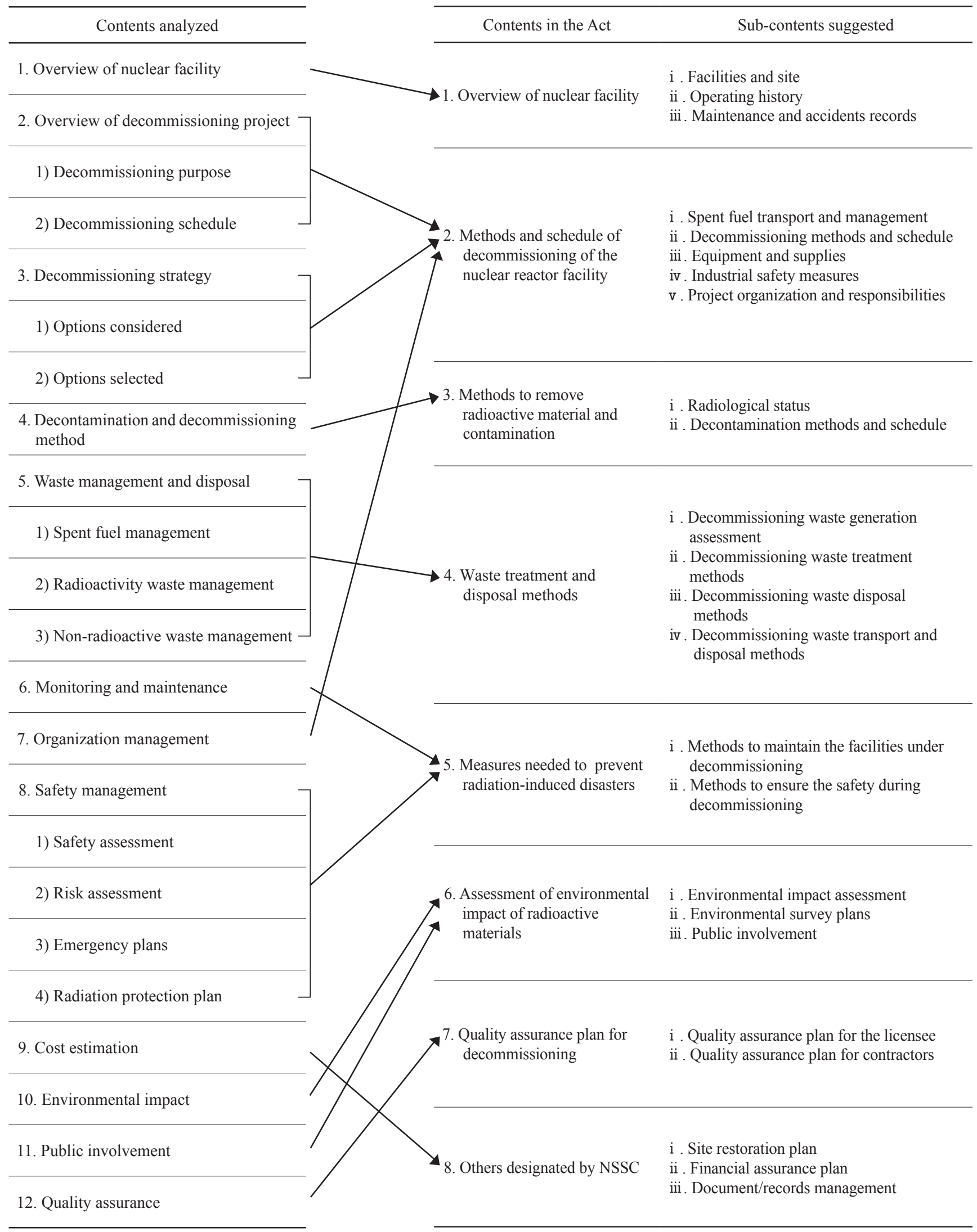


Table 8. The draft guidelines of the decommissioning plan for an NPP

\begin{tabular}{|c|c|}
\hline Items & Sub-items to be mentioned \\
\hline $\begin{array}{l}\text { 1. Overview of nuclear } \\
\text { facility }\end{array}$ & $\begin{array}{l}\text { i. Facilities and site } \\
\text { - To describe name, location and decommissioning entity of nuclear power reactor and its relevant facilities, hereafter, nuclear } \\
\text { reactor facilities. } \\
\text { - To describe the status of nuclear reactor facilities at that time when their decommissioning plan is being written. } \\
\text { - To describe impacts, in terms of integrity and maintenance of their structures and equipment. due to permanent cessation of } \\
\text { operation of the nuclear reactor facilities. } \\
\text { - To describe the status of the site based on the latest FSAR and environmental impact assessment report. } \\
\text { ii . Operating history } \\
\text { - To describe the operating history of the nuclear reactor facilities by year since the first issuance of the nuclear power reactor } \\
\text { operating license. } \\
\text { - To describe changes in operating license approved by NSSC since the first issuance of the nuclear power reactor operating } \\
\text { license. } \\
\text { iii. Maintenance and accidents records } \\
\text { - To describe the details of maintenance activities at the nuclear reactor facilities. } \\
\text { - To describe causes and follow-up measures of all incidents and accidents beyond INES (International Nuclear and } \\
\text { Radiological Event Scale) Level } 1 \text { rated in compliance with NSSC notice } 2012-11 \text {. } \\
\text { - To describe the details regarding it, such as date and time, location, material to be buried, type and form of radionuclides, } \\
\text { activity, and activity concentration, if there is any radioactive material landfill during the nuclear reactor facilities operation. }\end{array}$ \\
\hline
\end{tabular}

2. Methods and schedule of decommissioning of the nuclear reactor facility i. Spent fuel transport and management

- To describe results of characteristics assessment of all nuclear spent fuel at the interim spent fuel pool against acceptance criteria and their management method(including physical protection and safeguard measures) during the decommissioning period.

- To describe the management method of the storage facility during the decommissioning period, including the followings, if there is any separate spent fuel storage facility at the site:

- nuclear spent fuel storage type (dry vs. wet storage etc);

- its physical, chemical and radiological states according to storage type; and

- on-site management method until all nuclear spent fuel are moved to other facility or site.

- To describe the followings, if it is necessary to transport nuclear spent fuel:

- a plan to safely transport nuclear spent fuel to final destination; and

- its transport safety assessment, including integrity of nuclear spent fuel itself.

ii . Decommissioning methods and schedule

- To describe decommissioning method, technical backgrounds for selection of the decommissioning method, and preparation activities for decommissioning, i.e., activities after permanent operation cessation.

- To describe the methods for dismantlement and management of the following components:

- reactor vessel and internals, steam generator, pressurizer, large size reactor coolant piping, large radioactive equipment and components.

- To describe the order, starting and expected completion time of major decommissioning activities, and relationship between them.

- activities required for approval or permission by NSSC, such as nuclear fuel discharge, nuclear spent fuel management and storage, transport of major components should be described as in detail as possible.

- decommissioning schedule including expected starting and completion time of major decommissioning activities.

iii. Equipment and supplies

- To describe equipment and supplies for decontamination and dismantlement of the nuclear reactor facilities

- To describe the existing equipment and supplies and the new that will be needed to be installed or operated additionally for decommissioning.

- To describe the post-use management methods of the used equipment and supplies.

iv. Industrial safety measures

- To identify the potential non-radiological hazards related to decontamination and dismantlement of the nuclear reactor facilities and assess likelihoods of the hazards.

- models and methods to assess non-radiological hazards should be based on the industrial standards.

- To describe industrial safety related principles and standards to manage or control non-radiological hazards, and measures to secure workers' safety by minimizing non-radiological hazards.

$\mathrm{v}$. Project organization and responsibilities

- To describe the decommissioning entity, working groups, and their authorities and responsibilities during decommissioning period. 
3. Methods to remove radioactive material and contamination i . Radiological status

- To survey and analyze the radiological status inside and outside the nuclear reactor facilities, which has been or might be contaminated due to the nuclear reactor operation.

- Objects to be surveyed or analyzed: system and equipment, structures, surface soil, underground soil, surface water and underground water.

ii . Decontamination methods and schedule

- To describe decontamination method, schedule of decontamination activities, workforce, collective occupational doses, which will be selected or expected based on the radiological survey and analysis results.
4. Waste treatment and disposal methods i . Decommissioning waste generation assessment

- To describe the classification scheme for decommissioning wastes, and to assess sources, volume and radiological (or nonradiological) characteristics of decommissioning wastes according to the scheme.

- decommissioning waste generation assessment period: from the permanent cessation of operation to the completion of decommissioning

ii . Decommissioning waste treatment methods

- To describe principles for decommissioning waste treatment according to the waste classification scheme.

- To describe the treatment methods according to waste form(liquid, gaseous, and solid) for decommissioning radioactive wastes..

iii. Decommissioning waste disposal methods

- To describe on- and off-site storage methods according to the decommissioning wastes classification and their form - to describe methods to minimize waste volume to be disposed of.

- to describe the appropriate management and supervision methods during on-site storage period.

iv . Decommissioning waste transport and disposal methods

- To classify decommissioning wastes into radioactive and non-radioactive waste, and to describe principles to dispose of those wastes.

- To describe whether it will be disposed of or recycled for non-radioactive decommissioning waste, .

- To describe disposal methods according to the decommissioning wastes classification scheme for radioactive wastes.

- to describe the final disposal method according to the classification scheme.

- to describe on-site or other storage methods if the disposal site is not secured.

- To describe methods to safely transport radioactive waste to the final disposal site.
5. Measures needed to prevent radiationinduced disasters i . Methods to maintain the facilities under decommissioning

- To describe measures for their security of the nuclear reactor facilities under decommissioning

- To describe measures to maintain the following facilities:

- nuclear facilities structures, spent fuel handing and storage facilities, radioactive waste storage and treatment facilities, and other facilities needed for decommissioning (ventilation, power supply facilities etc.)

- To describe the fire protection plan for nuclear facilities.

- To describe the test and inspection plans on equipment needed for decommissioning of nuclear reactor facilities.

ii . Methods to ensure the safety during decommissioning

- To describe methods to protect the public from radiations during decommissioning.

- To describe methods to protect workers from radiations during decommissioning including the followings:

- radiation protection plan to keep occupational exposures ALARA;

- decontamination of system and equipment, and prevention of contamination dispersion;

- isolation between contaminated and non-contaminated areas;

- application of shielding and remote equipment;

- occupational dose goal setting;

- radiation monitoring;

- training and education; and

- others.

- To describe criteria for radiation zoning in the process of decommissioning.

- To describe the radiation emergency response plan against radiation emergencies that might occur in the middle of decommissioning. 
Jungmin Lee. et al : Development of the draft guidelines of the decommissioning plan for a nuclear power plant in Korea

Items

Sub-items to be mentioned

\begin{tabular}{|c|c|}
\hline \multirow{10}{*}{$\begin{array}{l}\text { 6. Assessment of } \\
\text { environmental } \\
\text { impact of radioactive } \\
\text { materials }\end{array}$} & i . Environmental impact assessment \\
\hline & - To describe the estimated occupational doses of decommissioning workers due to radiations emitted from adjacent \\
\hline & nuclear facilities that are still operating at that time when the decommissioning plan is being written. \\
\hline & - To describe radiological impacts due to normal decommissioning of the nuclear reactor facilities. \\
\hline & - To describe radiological impacts due to accidents in the middle of decommissioning of the nuclear reactor facilities. \\
\hline & $\begin{array}{l}\text { - To describe non-radiological impacts on environment due to decommissioning. } \\
\text { ii . Environmental survey plans }\end{array}$ \\
\hline & - To describe the pre-decommissioning environmental survey plan, based on the environmental impact assessment. \\
\hline & $\begin{array}{l}\text { To describe the environmental survey plan on items that might be impacted during decommissioning, based on the pre- } \\
\text { decommissioning environmental survey plan. }\end{array}$ \\
\hline & $\begin{array}{l}\text { - To refer to NSSC notice 2012-5 for environmental survey planning, know-how on survey, survey data processing, and } \\
\text { survey data keeping, etc. } \\
\text { iii. Public involvement }\end{array}$ \\
\hline & $\begin{array}{l}\text { - To describe procedure and methods to collect and reflect the public opinions on the decommissioning plan of the nuclear } \\
\text { reactor facilities for local residents and head of local administrative agencies in the regions designated by NSSC. }\end{array}$ \\
\hline \multirow{6}{*}{$\begin{array}{l}\text { 7. Quality assurance plan } \\
\text { for decommissioning }\end{array}$} & i. Quality assurance plan for the licensee \\
\hline & $\begin{array}{l}\text { - To describe the quality assurance plan to ensure qualities of all design, procurement, construction, and services related to } \\
\text { decommissioning of the nuclear reactor facilities. }\end{array}$ \\
\hline & ii . Quality assurance plan for contractors \\
\hline & - To describe the quality assurance plan to guarantee qualities of all activities of contractors (including sub-contractors) \\
\hline & participating in decommissioning of the nuclear reactor facilities, including education, training, managing and \\
\hline & supervising for their workers. \\
\hline \multirow{11}{*}{$\begin{array}{l}\text { 8. Others designated by } \\
\text { NSSC }\end{array}$} & i. Site restoration plan \\
\hline & - To describe methods to restore or reuse the nuclear reactor facilities site. \\
\hline & $\begin{array}{l}\text { - To methods to comply with the radiological criteria related to site reuse (restricted or unrestricted release, or release } \\
\text { according to the third criteria) }\end{array}$ \\
\hline & $\begin{array}{l}\text { - To describe the final radiation survey plan to confirm whether to comply with the related radiological criteria for restricted } \\
\text { or unrestricted use of the site. }\end{array}$ \\
\hline & ii . Financial assurance plan \\
\hline & $\begin{array}{l}\text { - To estimate the total cost over the entire decommissioning period using the decommissioning schedule and site specific } \\
\text { data }\end{array}$ \\
\hline & - To provide the financial assurance plan and means for the total decommissioning cost. \\
\hline & iii. Document/records management \\
\hline & - To describe methods to maintain the followings till license termination of the nuclear reactor facilities: \\
\hline & $\begin{array}{l}\text { n characteristics } \\
\text { e characteristics (including generation }\end{array}$ \\
\hline & $\begin{array}{l}\text { - information on decommissioning waste characteristics (including generation location, radiation source, waste mass and } \\
\text { volume, waste class, and important radionuclides, etc.) }\end{array}$ \\
\hline
\end{tabular}

로 하였다. 다만 원자로시설에 대한 개요가 필요하다는 판 단 하에 이를 해체계획서의 첫 번째 항목으로 두었다. 둘 째, 첫 번째 단계에서 정한 대항목에 대한 세부 기재항목은 IAEA, 미국, 영국, 프랑스 등의 지침을 분석한 결과를 토대 로 도출하였다. 여기에서 도출된 기재항목을 앞 단계에서 고려한 8 개 대항목(시설의 개요 +「원자력안전법」 제 28 조제 2 항에서 규정한 7 개 항목)에 대응을 시켰다. 상기의 2 가지 원칙에 따라 최종적으로 도출한 국내 해체계획서 작 성항목(안)을 Table 7에 정리하였다.

Table 8은 Table 7의 기재항목에 대한 세부 기재사항
을 정리한 것이다. 이들 세부 기재사항은 미국, 영국, 프 랑스의 지침을 바탕으로 국내 현행법을 반영하여 개발하 였다.

사용후핵연료와 관련하여 비교대상 국가의 해체계획 서 작성지침은 자국의 상황에 따라 관리방안을 제시하도 록 하고 있다. 그러나 우리나라는 사용후핵연료 관리 정책 을 아직까지 확정하지 않았고 중간 저장시설도 확보하지 못한 상황이다. 중간 저장시설의 경우, 공론화를 시작으로 부지 선정 및 건설완료에 이르기까지 최소 10 년 이상 걸 린다는 점을 감안할 때, 해체 기간 중 부지 내에 남아있을 
Jungmin Lee. et al : Development of the draft guidelines of the decommissioning plan for a nuclear power plant in Korea

사용후핵연료를 중간 저장시설에 인도할 때까지 안전하 게 관리할 수 있는 방안을 마련할 필요가 있다. 이러한 점 을 감안하여 해체계획서에 사용후핵연료 관리 방안을 기 술하도록 하였다.

\section{4. 논의 및 결론}

최근 고리 1 호기와 월성 1 호기의 계속운전에 대해 사 회적 논란이 벌어지고 있다. 그러나 우리나라는 원자로시 설 건설 및 운영단계에 대한 법체계는 잘 마련되어 있으 나, 원자로시설의 영구정지서부터 해체완료에 이르는 기 간에 대한 안전규제체계가 미비한 상황이다. 이러한 상황 을 반영하듯, 2011년 7월 국제원자력기구는 우리나라를 대상으로 수행한 통합규제검토서비스(Integrated Regulatory Review Service)를 통해 원자로 건설 단계 시부터 해 체 계획을 수립하고 운영기간 중 주기적으로 갱신할 것을 권고하였다.

우리나라의 경우「원자력안전법」제 28 조(발전용원 자로 및 관계시설의 해체)와 동법 시행규칙 제26조(원자 로시설의 해체계획 승인신청)에서 원자로시설 해체와 관 련한 사항을 규정하고 있으나, 이들 규정은 원자로 해체 전 원자력안전위원회에 해체계획서를 제출해야 한다는 사실 과 이 해체계획서에 포함되어야 하는 일반 항목만을 정하 고 있을 뿐이다. 이 때문에 해체사업자가 해체계획서를 작 성하는데 애로를 겪을 가능성이 높으며, 규제기관 측면에 서도 원자로시설 해체의 안전성 및 환경영향을 확인하는 데 한계를 느낄 수가 있다.

이에 본 연구에서는 원자로시설을 해체한 경험과 우리 나라보다 선진화된 원자로시설 해체 요건을 수립하고 있 는 IAEA, 미국, 영국, 프랑스의 관련 지침을 비교분석하 여, 우리나라 실정에 맞은 원자로시설 해체계획서 작성지 침(안)을 개발하였다. 이를 위해 첫째, 기존 법체계와 일관 성을 유지하도록 해체계획서에 포함해야 하는 대항목을 $\ulcorner$ 원자력안전법」제 28 조제 2 항에서 규정한 항목을 따르는 것으로 하였다. 다만 원자로시설에 대한 개요가 필요하다 는 판단 하에 이를 해체계획서의 가장 앞에 두는 것으로 하 였다. 둘째, 첫 번째 단계에서 정한 대항목에 대한 세부 기 재항목은 IAEA, 미국, 영국, 프랑스 등의 지침을 분석한 결 과를 토대로 도출하였다. 여기에서 도출된 기재항목을 앞 단계에서 고려한 8 개 대항목(시설의 개요 $+\ulcorner$ 원자력안전 법」제 28 조제 2 항에서 규정한 7 개 항목)에 대응을 시켰다. 상기 2 가지 원칙을 바탕으로 국내 원자로시설 해체계획서
작성지침(안)을 개발하였다.

우리나라의 원자력안전법령 구비 현황을 고려했을 때, 본 연구에서 개발한 원자로시설 해체계획서 작성지침(안) 은 국내 원자로시설 해체 관련 법령을 정비하는데 디딤돌 역할을 할 수 있을 것으로 판단한다. 특히 해체사업자가 원 자로시설을 해체하고자 할 때 미리 준비해야 할 사항을 알 려줌으로써 원자로시설 해체사업의 안정적이고 효과적인 추진에 도움을 줄 것으로 기대한다.

\section{감사의 글}

이 논문은 원자력안전위원회 원자력안전(원자력안전 규제기술)연구개발사업의 지원을 받았음을 밝히며 이에 감사드립니다.

\section{REFERENCES}

[1] IAEA, "Decommissioning of Facilities Using Radioactive Material", WS-R-5, International Atomic Energy Agency, Vienna, pp. 1-38 (2006).

[2] IAEA, "Decommissioning of Nuclear Power Plants and Research Reactors", WS-R-2.1, International Atomic Energy Agency, Vienna, pp. 1-52 (1999).

[3] IAEA, "Standard Format and Safety Related Decommissioning Documents", Safety Reports Series No. 45, International Atomic Energy Agency, Vienna, pp. 1-64 (2005).

[4] U.S. NRC, REGULATORY GUIDE 1.184, "Decommissioning of Nuclear Power Reactor," Washington, DC, pp. 1-20 (2000).

[5] U.S. NRC, REGULATORY GUIDE 1.185, "Standard Format and Content for Post-Shutdown Decommissioning Activities Report," Washington, DC, pp. 1-13 (2000).

[6] J.S. Hong, Y.J. Lee and Y.C. Lee, "Nuclear policy, R\&D Trend and Issues after Fukushima's Accidents" in Trend Brief for Science Technology and Research Development Project, Korea Institute of S\&T Evaluation and Planning, vol. 5, pp. 1-31 (2012).

[7] Y.I. You and J.H. Kim, KETEP Issue Paper, Implication by policy trend for UK and Major nuclear nation, 
Jungmin Lee. et al : Development of the draft guidelines of the decommissioning plan for a nuclear power plant in Korea

Korea Institute of Energy Technology Evaluation and

Planning, vol. 5, pp. 1-14 (2013).

[8] S.K. Ahn, Improvement of Regulatory System for decommissioning of Nuclear Power Plants, Korea Institute of Nuclear Safety, pp. 1-60, KINS/RR476(2007).

[9] HSE, Guidance for Inspectors on Decommissioning of Nuclear Licensed Sites, Health \& Safety Executive and Nuclear Safety Directorate, pp. 1-57 (2013).

[10] CEA, Radioactive Waste Management and Decommissioning in France, Andra, ASN, CEA, IRSN, pp. 1-38 (2013). 